\title{
Robin W. G. Horton (1932-2019): his life and work
}

Robin Horton, one of the world's finest intellectuals, one of anthropology's most original, brilliant and influential scholars, and a most provocative philosopher of African indigenous modes of thought in the last fifty years, died on 28 November 2019. He was born an English man, trained at Oxford, lived and died a Kalabari (Niger Delta, Nigeria) gentleman, and was buried in Buguma on 18 January 2020 as a member of royalty by the Kalabari-Ijaw. He came to them as a learner and they took him in as their own. He became an expert in their religion, culture and history, and eventually grew into a wise elder they turned to in order to understand their culture, history and rituals. He also taught the world how to interpret Kalabari religion and to take its philosophical ideas seriously.

Horton - influenced by Tylor and Frazer - studied African religions always in the context of cognitive science and comparative philosophy. His scholarship has proved important and enduring in our understanding of the philosophy of African traditional religions (ATRs). His theory of religious conversion, more than four decades after he crafted it, is still generating enormous scholarly attention.

Horton, who preferred the scholarly essay format to the book format to publish his ideas, was noted for works that were not only brilliant but were also groundbreaking and ground-clearing. His essays were lucid and methodical, as theoretically sophisticated as they were rooted in ethnography, and they proved enormously successful, placing ATRs' philosophy and the Kalabari pattern of thought within a universal narrative of humanity's engagement with reality, God and the quest for explanation.

This philosopher-anthropologist was born in London on 27 October 1932 to William Gray Horton, who was a lieutenant colonel in the Scots Guard, and his wife Gwendolen (née Le Bas). William Gray came to Britain from the United States. Robin's grandfather was the American impressionist painter William Samuel Horton.

Robin Horton obtained a bachelor's degree (first-class honours) in philosophy, psychology and physiology from New College, Oxford in 1956. Before going to Oxford - after completing school at Harrow - he was sent to Nigeria to do his national service. He served in the Royal West Africa Frontier Force (1950-51) in Kaduna. On leaving Oxford he went to University College London for his doctorate in anthropology, which he never completed. He was advised by Professor Daryll Forde, his supervisor, to study the Kalabari and so he returned to Nigeria in 1962 for his research, and he fell in love with a Kalabari woman, Hanna Douglas. This woman died in childbirth in 1964 and he married another Kalabari woman (Ibieneba Abo-Briggs), with whom he had a daughter, Edwina.

Horton focused his anthropological career on the Kalabari and stayed in Nigeria for the rest of his life. His academic career began at the University of Ife (now Obafemi Awolowo University). He transferred to the University of Ibadan in 1965, staying there until 1969. He returned to Ife in 1970 and in 1978 he left it again and moved to the University of Port Harcourt (Niger Delta), where he served until his retirement in 2005 as a professor of philosophy and religion. 
Horton's scholarship compelled attention because of two main theses (arising out of his 'intellectualist approach' to religion) that he pursued in various forms throughout his long career. He argued that African traditional religious theory in crucial aspects is more akin to modern natural science than to modern religion, especially Protestant Christianity. According to him, ATRs are engaged in 'explanation, prediction, and control', and this is an orientation that they share with modern natural sciences. His point is that theories in natural sciences and traditional religions are similar in certain relevant aspects. Working from this understanding, he systematically developed an analogy between natural science and ATRs, without actually arguing that traditional religions are sciences.

His articles on conversion refocused and relaunched the study of religious change. Horton argued that religious conversion or change is related to social transformation. More precisely, as a people in micro-worlds encounter and interact with the wider worlds, macrocosms, as their circumstances are transformed, their religious need for explanation, prediction and control changes. This nudges them to convert to a new religion that better explains events in their expanded micro-macro world.

For these and other powerful ideas, which we cannot recount here because of space limitations, Horton was invited to give the prestigious Frazer Lecture in 1987 and he was elected fellow of the British Academy in 1996. His ideas were original, persuasive and provocative. His mastery of sophisticated ideas across multiple fields demonstrated to his readers the weighty benefits of a transdisciplinary approach to knowledge production.

British anthropologist and historian J. D. Y. Peel (1941-2015) offered this assessment of Horton's scholarship:

I can think of no other living anthropologist who has combined such a contribution to the discipline at the highest level of theory, with such a deep and long-lasting familiarity with 'his people' as Robin Horton has ... Horton has worked so long in Buguma, and has got to know it so well over such a long period of time (which has seen such changes), that he is now the principle ritual expert in the community, the main repository of the knowledge of its history and culture. ${ }^{1}$

Professor Robin Horton was a proper, genuine, complete (krakra) Kalabari gentleman. He was a highly respected repository of the lore of the community and embodied the refined virtues and the aristocratic ideals of the Kalabari Igbo masquerade, which he brilliantly analysed in his 1966 essay. ${ }^{2}$ He was even a 'diplomat' for the Ijaw ethnic group. In one of our conversations in the 1990s, he told me that, during the Nigerian Civil War (1967-70), he lobbied the governments in London and Washington DC on behalf of the Ijaw people, asking them to protect the Ijaw. He shuttled between London and Washington multiple times to inform the global powers about the Ijaw stance during the crisis. In recognition of Horton's contributions to Niger Delta studies and to the Ijaw people, one of his former students, Ambassador Boladei Igali, announced at the funeral ceremony that he would

\footnotetext{
${ }^{1}$ J. D. Y. Peel (2007), 'Unpublished short biography of Robin Horton', p. 5.

'Robin Horton (1966) 'Igbo: an ordeal for aristocrats', Nigerian Magazine 90: 168-83.
} 
endow a chair in Ijaw Studies at the University of Port Harcourt in honour of Robin William Gray Horton.

\section{Bibliography}

This bibliography is based on a compilation by Nimi Wariboko, revised by Richard Bartholomew. Some of Robin Horton's earlier works were published under the name 'W. R. G. Horton', and in such cases this has been indicated. Reprints and translations are listed alongside the first appearance of a particular work, although in cases where the republication represents a revision it has been given its own entry as well.

\section{7}

(As W. R. G. Horton) 'Report on wild flowers', Annual Report of the Harrow Natural History Society 3 (1): 3-18.

\section{4}

(As W. R. G. Horton) 'The Ohu system of slavery in a northern Ibo village-group', Africa 24 (4): 311-36.

\section{6}

(As W. R. G. Horton) 'God, man, and the land in a northern Ibo village-group', Africa 26 (1): 17-28.

(As W. R. G. Horton) 'Review of K.O. Dike, Trade and Politics in the Niger Delta, 1830-1885 (Oxford: Clarendon Press, 1956)', Man 56 (August): 115-16.

\section{7}

(As W. R. G. Horton) 'Review of S. F. Nadel, The Theory of Social Structure (Melbourne: Melbourne University Press)', Blackfriars 38 (44): 238-9.

\section{8}

(As W. R. G. Horton) 'Review of B. Lindskog, African Leopard Men (Uppsala: Almqvist \& Wiksells Boktryckeri, 1954)', Man 58 (May): 83.

\section{9}

(As W. R. G. Horton) 'Review of J. Melville and F. S. Herskovits, Dahomean Narrative: a cross-cultural analysis (Evanston: Northwestern University Press, 1958)', Africa 29: 311-13.

\section{0}

'A definition of religion, and its uses', Journal of the Royal Anthropological Institute 90 (2): 201-26. Reprinted in Patterns of Thought (1993), pp. 19-49, 390-1. 
The Gods as Guests: an aspect of Kalabari religious life. Nigeria Magazine, Special Publications 3.

'New Year in the Delta: a traditional and a modern festival', Nigeria Magazine 67: 256-97.

\section{1}

'Destiny and the unconscious in West Africa', Africa 31 (2): 110-16.

(As W. R. G. Horton) 'Social science, logical or psychological impossibility?', Man 61: 11-15.

'Three Nigerian novelists', Nigeria Magazine 70: 218-24.

'Review of King Kong (South African musical)', Nigeria Magazine 69: 194-5.

\section{2}

'The high God: a comment on Father O'Connell's paper', Man 62: 137-40.

'The Kalabari world-view: an outline and interpretation', Africa 32 (3): 197-220.

'Review of G. Lienhardt, Divinity and Experience: the religion of the Dinka

(London: Oxford University Press, 1961)', Africa 32 (1): 78.

'Review of D. F. Pocock, Social Anthropology', Man 62: 171.

\section{3}

(As W. R. G. Horton) 'The boundaries of explanation in social anthropology', Man 63 (6): 8-11.

'The Kalabari Ekine society: a borderland of religion and art', Africa 33 (2): 94

114. Revised version in A Hundred Years of Buguma History (1991), pp. 101-26.

\section{4}

'Kalabari culture and history I', African Notes 2 (1): 5-7.

'Kalabari culture and history II', African Notes 2 (3): 16-17.

'Kalabari diviners and oracles', $O D U 1$ (1): 3-16.

'Men and their gods' in M. Douglas, G. Barry, J. Bronowski, J. Fisher and J. Huxley (eds), Man in Society: patterns of human organization (London: Macdonald), pp. 104-25.

'Ritual man in Africa', Africa 34 (2): 85-104. Reprinted in M. H. Fried (ed.), Readings in Anthropology: Volume II (New York NY: Crowell, 1968), pp. 651-73.

\section{5}

'Duminea, a festival for the water spirits in the Niger Delta', Nigeria Magazine 86: 187-93.

Kalabari Sculpture ([Lagos]: Department of Antiquities, Federal Republic of Nigeria).

'A note on recent finds of brasswork in the Niger Delta', ODU 2 (1): 76-91.

'Review of W. Fagg and M. Plass, African Sculpture: an anthology (London: Studio Vista / New York: E. P. Dutton)', Nigeria Magazine 86: 216-17. 


\section{6}

'Conference: “The High God in Africa”, $O D U 2$ (2): 87-95.

'Igbo: an ordeal for aristocrats', Nigeria Magazine 90: 168-83.

\section{7}

'African traditional thought and Western science. Part I: From tradition to science', Africa 37 (1): 50-71. Reprinted with Part II in Patterns of Thought (1993), pp. 197-258, 420-4; shortened version of both parts in Rationality (1970); French-language version in La pensée métisse (1990).

'African traditional thought and Western science. Part II: The "closed" and "open" predicaments', Africa 37 (2): 155-87. Reprinted with Part I in Patterns of Thought (1993), pp. 197-258, 420-4; shortened version of both parts in Rationality (1970); French-language version in La pensée métisse (1990).

'Ikaki - the tortoise masquerade', Nigeria Magazine 94: 226-39.

'Philosophy and African studies' in D. Brokensha and M. Crowder (eds), Africa in the Wider World: the inter-relationship of area and comparative studies (Oxford: Pergamon Press), pp. 261-91.

(F. Speed and R. Horton (directors)) Duminea: a festival for the water-spirits (London: Royal Anthropological Institute). [18-minute $16 \mathrm{~mm}$ documentary.]

\section{8}

'Neo-Tylorianism: sound sense or sinister prejudice?', Man 3 (4): 625-34. Reprinted in Patterns of Thought (1993), pp. 53-62, 392-3.

(T. Tamuno and W. R. G. Horton) 'The changing position of secret societies and cults in modern Nigeria', African Notes 5 (2): 36-62.

\section{9}

'From fishing village to city-state: a social history of New Calabar' in M. Douglas and P. M. Kaberry (eds), Man in Africa (London: Tavistock Publications), pp. 38-60. Reprint: London: Routledge, 2001.

'Types of spirit possession in Kalabari religion' in J. Beattie and J. Middleton (eds), Spirit Mediumship and Society in Africa (New York NY: Africana Publishing), pp. 14-49. [Table of contents gives title as 'Kalabari region'.]

\section{0}

'African traditional thought and Western science' in B. R. Wilson (ed.), Rationality (Oxford: Basil Blackwell), pp. 131-71. [Shortened version of the 1967 papers.]

'A hundred years of change in Kalabari religion' in J. Middleton (ed.), Black Africa: its peoples and their cultures today (New York NY: CollierMacmillan), pp. 192-211. [Table of contents gives title as 'A 100'.]

'Ikpataka Dogi: a Kalabari funeral rite', African Notes 5 (3): 57-72.

'The romantic illusion: Roger Bastide on Africa and the West', $O D U$ 3: 87-115. 
1971

'African conversion', Africa 41 (2): 85-108. [French-language summary in Africa 41 (3) 244-5.]

'On taking the enemy's measure' in R. G. Armstrong (ed.), Papers Presented at a Special Seminar on the Traditional Background to Medical Practice in Nigeria, April 20-23, 1966. Institute of African Studies Occasional Publication 25 (Ibadan: University of Ibadan Institute of African Studies in collaboration with University College Hospital), pp. 36-45.

'Stateless societies in the history of West Africa' in J. F. A. Ajayi and M. Crowder (eds), History of West Africa: Volume 1 (London: Longman), pp. 78-119.

\section{2}

'Spiritual beings and elementary particles - a reply to Mr Pratt', Second Order 1 (1): 21-33.

\section{3}

'Lévy-Bruhl among the scientists - a reply to Mr Skorupski', Second Order 2 (1): $14-30$.

'Lévy-Bruhl, Durkheim and the scientific revolution' in R. Horton and R. H. Finnegan (eds), Modes of Thought: essays on thinking in Western and non-Western societies (London: Faber and Faber), pp. 249-305. Reprint: Eugene OR: Wipf and Stock, 2017. Reprinted in Patterns of Thought (1993), pp. 63-104, 393-400. Spanish-language translation: Levy-Bruhl, Durkheim y la revoluciòn cientifica. Cuadernos Anagrama 162 (Barcelona: Anagrama, 1980).

'Paradox and explanation: a reply to Mr Skorupski I', Philosophy of the Social Sciences 3 (3): 231-56. Reprinted with Part II in Patterns of Thought (1993), pp. 259-300, 424-33.

'Paradox and explanation: a reply to Mr Skorupski II', Philosophy of the Social Sciences 3 (4): 289-312. Reprinted with Part I in Patterns of Thought (1993), pp. 259-300, 424-33.

(R. H. Finnegan and R. Horton) 'Introduction' in R. Horton and R. H. Finnegan (eds), Modes of Thought: essays on thinking in Western and non-Western societies (London: Faber and Faber), pp. 13-63. Reprint: Eugene OR: Wipf and Stock, 2017.

(R. H. Finnegan and R. Horton (eds)) Modes of Thought: essays on thinking in Western and non-Western societies (London: Faber and Faber). Reprint: Eugene OR: Wipf and Stock, 2017.

\section{4}

(M. Gluckman, G. Dieterlen and R. Horton) 'Daryll Forde: further tributes', Africa 44 (1): 1-10 [8-10].

\section{5}

'Ekineba: a forgotten myth', Oduma 2: 33-6.

'On the rationality of conversion. Part I', Africa 45 (3): 219-35.

'On the rationality of conversion. Part II', Africa 45 (4): 373-99. 
1976

'Professor Winch on safari', European Journal of Sociology / Archives Européennes de Sociologie 17 (1): 157-80. Reprinted in Patterns of Thought (1993), pp. 138$60,406-9$.

'Understanding traditional African religion: a reply to Professor Beattie', Second Order 3: 3-29.

(R. Horton and J. D. Y. Peel) 'Conversion and confusion: a rejoinder on Christianity in Eastern Nigeria', Canadian Journal of African Studies 10 (3): 481-98.

\section{7}

'Traditional thought and the emerging African philosophy department: a comment on the current debate', Second Order 6 (1): 64-80.

\section{9}

'Ancient Ife: a reassessment', Journal of the Historical Society of Nigeria 9 (4): 69-149.

'Material-object language and theoretical language: towards a Strawsonian sociology of thought' in S. C. Brown (ed.), Philosophical Disputes in the Social Sciences (Brighton: Harvester), pp. 197-224.

'Reply to Martin Hollis' in S. C. Brown (ed.), Philosophical Disputes in the Social Sciences (Brighton: Harvester), pp. 233-40.

\section{2}

'Tradition and modernity revisited' in M. Hollis and S. Lukes (eds), Rationality and Relativism (Oxford: Basil Blackwell), pp. 201-60. Reprinted in Patterns of Thought (1993), pp. 301-46, 433-9; French-language adaptation in La pensée métisse (1990).

\section{3}

'Social psychologies: African and Western' in M. Fortes, Oedipus and Job in West African Religion: with an essay by Robin Horton (Cambridge: Cambridge University Press), pp. 41-82.

\section{4}

'Judaeo-Christian spectacles: boon or bane to the study of African religions?', Cahiers d'Études Africaines 24 (96): 391-436. Reprinted in Patterns of Thought (1993), pp. 161-93, 409-20.

\section{8}

'Michael Crowder: some recollections of his early days', Canadian Journal of African Studies 22 (2): 388-90. [Memorial service address.] 


\section{9}

(J. F. A. Ajayi and R. Horton) 'Michael Crowder, 1934-88', Africa 59 (1): 110-18.

\section{0}

'La pensée traditionalle de l'Afrique et la science occidentale' in Y. Preiswerk and J. Vallet (eds), La pensée métisse: croyances africaines et rationalité occidentale en questions (Geneva and Paris: Graduate Institute Publications and Presses Universitaires de France), pp. 45-67. [French-language version of the 1967 papers.]

'La tradition et la modernité revisitées' in Y. Preiswerk and J. Vallet (eds), La pensée métisse: croyances africaines et rationalité occidentale en questions (Geneva and Paris: Graduate Institute Publications and Presses Universitaires de France), pp. 69-124. [French-language translation of the chapter in Rationality (1982).]

\section{1}

(Uncredited) 'The Kalabari Ekine society' in T. V. Erekosima, K. Lawson and O. MacJaja (eds), A Hundred Years of Buguma History in Kalabari Culture (Lagos: Sibon Books), pp. 101-26. [Revision of 1963 article.]

'Relevance of Kalabari religion in modern times' in T. V. Erekosima, K. Lawson and O. MacJaja (eds), Buguma 1984 Centenary Symposia on Kalabari (Lagos: Sibon Books), pp. 82-103.

\section{2}

'The economy of Ife from $c$. AD 900-c. AD 1700' in I. A. Akinjogbin (ed.), The Cradle of a Race: Ife from the beginning to 1980 (Port Harcourt: Sunray Publications), pp. 122-47.

\section{3}

Patterns of Thought in Africa and the West: essays on magic, religion and science (Cambridge: Cambridge University Press). ['Introduction' (pp. 1-15, 388-90); 'Back to Frazer?' (expansion of 1987 Frazer Lecture - pp. 105-37, 400-6); 'Postscript' (pp. 347-87, 439-46); and reprints of earlier works noted above.]

\section{5}

'The Niger-Congo diaspora: language, geography and history' in E. Nolue Emenanjo and O.-M. Ndimele, Issues in African Languages and Linguistics: essays in honour of Kay Williamson (Aba: National Institute for Nigerian Languages), pp. 306-39.

'Sokari Douglas Camp: Ekine woman in London' in R. Horton and S. Hubbard, Play and Display: steel masquerades from top to toe (London: Museum of Mankind), pp. 1-8.

(R. Horton, J. Thorburn and S. D. Camp) Alagba: a water spirit masquerade (London: After Image). [45-minute DVD documentary.] 
1998

'Some fresh thoughts on eastern Ijo origins, expansions and migrations' in N. C. Ejituwu and E. J. Alagoa, The Multi-disciplinary Approach to African History: essays in honour of Ebiegeri Joe Alagoa (Port Harcourt: University of Port Harcourt Press), pp. 217-22.

\section{5}

'Alagoa: oral tradition and the multi-method approach' in N. C. Ejituwu and A. E. Afigbo, History Concourse - 2005: a celebration of the life and work of Professor Ebiegberi Joe Alagoa (Port Harcourt: Onyoma Research Publications), pp. 29-42.

\section{0}

'For Kay Williamson from her neighbour', Africa 80 (1): 170-1.

\section{Undated}

Ijo Ritual Sculpture, with Photographs by Robin Horton and Noah Onwuka: Volume 1 (Royal Anthropological Institute, MS 345).

'Religion explained: on two modern theories.' [Unpublished paper, 2015.]

'Traditional thought and the emerging African philosophy department: a reply to Dr Hallen.' [Unpublished paper.]

Untitled paper about the Ijo of the Rivers Province (Royal Anthropological Institute, MS 349).

Nimi Wariboko

Nimi Wariboko is the Walter G. Muelder Professor of Social Ethics at Boston University. Email: nimiwari@bu.edu 